\title{
ANALISIS PERAN INTERMEDIASI PERBANKAN DI INDONESIA PADA TAHUN 2004-2008
}

\author{
Oleh: \\ Astri Widiantini \\ Staff Kantor Imigrasi Kota Malang \\ E-mail/No. Hp: - /0341477145
}

\begin{abstract}
This Research is to know influence of CAR, NPL, Rate Of Interest of SBI to Ability Of Monetary Intermediasi (LDR) and to know most variable influence of LDR. Analysis method which used in this research quantitative descriptive method by using statistical analysis that is analysis of regresi doubled linear, Statistical test and classic assumption test. $\quad$ From result of research indicate that NPL have more influence signifikan to LDR compared to CAR and of SBI. Because NPL influence to amount of channeling of banking credit. Pursuant to conclusion above, expected banking earn more optimal its function him by taking care of storey;level assess CAR, lessening location of fund SBI as well as more selective again channeling of credit value of NPL remain to lower
\end{abstract}

Keywords: capital adequacy ratio, non-performing loan, and loan to deposit ratio

\section{PENDAHULUAN}

Dalam penyaluran kredit, bank dipengaruhi oleh faktor internal dan eksternal. Menurut Muljono (1996), faktor internal yang mempengaruhi penyaluran kredit diantaranya kemampuan bank dalam menghimpun dana, posisi modal (capital adequacy ratio), aktiva tertimbang menurut resiko, batas maksimum pemberian kredit), kualitas aktiva produktifnya dan faktor produksi yang tersedia di bank. Sedangkan untuk faktor eksternal dipengaruhi oleh diantaranya peraturan moneter yang berlaku, persaingan, situasi sosial politik, karakteristik usaha nasabah, suku bunga. Sebagai akibat dari krisis ekonomi sekarang ini, banyak masyarakat yang takut dan kurang percaya dengan perbankan. Masyarakat enggan menabung karena takut dananya tidak dapat dikembalikan. Sehingga pertumbuhan DPK (dana pihak ketiga) menurun dan menyebabkan penyaluran kredit menjadi terhambat. Selain itu, akibat lain dari krisis ekonomi yang terjadi adalah banyaknya kasus kredit macet atau kredit bermasalah sehingga berpengaruh terhadap permodalan bank. Ketidakmampuan pembayaran kredit ini yang menyebabkan NPL (NonPerforming Loan) semakin meningkat.

Permodalan menjadi indikator yang paling penting pada perbankan. Berdasarkan peraturan dari Bank Indonesia No. 3/21/PBI/2001, setiap bank wajib memenuhi kecukupan modal sebesar 8\%. Tingkat kecukupan modal pada perbankan diwakilkan dengan rasio capital adequacy ratio (CAR). CAR memperlihatkan seberapa besar jumlah seluruh aktiva bank yang mengandung resiko, yang dibiayai dari modal sendiri. Jika tingkat kecukupan modal meningkat maka penyaluran kredit juga akan meningkat.

NPL (Non-Performing Loan) atau kredit bermasalah merupakan kasus yang saat ini menjadi petaka bagi perbankan. Ini terjadi karena para peminjam tidak 
dapat melunasi pinjaman sesuai dengan kesepakatan, yang kemungkinan berasal dari faktor kesengajaan peminjam seperti penyimpangan yang dilakukan debitur maupun dari faktor ketidaksengajaan peminjam seperti ketidakmampuan dalam pembayaran karena kondisi ekonomi yang buruk.

Efek buruk dari permasalahan ini menyebabkan perbankan sendiri tidak mau mengambil resiko yang besar jika tetap melakukan penyaluran kredit kepada masyarakat. Karena bisa menyebabkan kondisi perbankan semakin memburuk terutama pada posisi CAR. Saat ini perbankan lebih memfokuskan dana yang telah dihimpun diinvestasikan ke SBI (Sertifikat Bank Indonesia). SBI merupakan instrumen kebijakan moneter yang beralih fungsi menjadi alat investasi yang menguntungkan, lebih aman dan beresiko kecil. Dengan SBI, perbankan tidak perlu resah apabila dananya diinvestasikan kedalamnya karena dinilai cukup memberikan pendapatan bagi bank melalui dari return SBI dibandingkan jika bank menyalurkan kredit kepada masyarakat yang beresiko lebih besar. Bukan berarti bank hanya menyalurkan dananya pada SBI saja, tetapi penyaluran kredit pada perbankan masih tetap dilakukan tetapi dalam skala yang kecil dan melalui proses analisi yang lebih teliti serta memprediksi kemungkinan-kemungkinan yang akan terjadi. Perbankan sedikit merasa cukup diuntungkan dengan adanya krisis ekonomi karena tingkat permintaan kredit menurun karena tingkat suku bunga yang terus mengalami peningkatan. Hal ini dapat dimanfaatkan oleh perbankan untuk memperbaiki kinerja perbankan melalui penghimpunan dana masyarakat (DPK) sebelum pemerintah menurunkan tingkat suku bunga.
Kebijakan-kebijakan yang diambil Bank Indonesia untuk mendorong fungsi intermediasi (bidang perkreditan) diantaranya: 1. Melonggarkan ketentuan perhitungan aset tertimbang menurut resiko, (ATMR) bagi sektor yang low risk; 2. Mengeluarkan regulasi yang mendukung pemberdayaan proyekproyek pemerintah yang strategis; 3 . Menaikkan presentase giro wajib minimum (GWM) bagi bank-bank yang LDR nya dibawah 50\%; dan 4. Mewajibkan bank-bank melakukan ekspansi ke segmen UMKM dalam presentase tertentu (misalnya 20\%-30\% dari rencana ekspansi kreditnya).

Untuk mengembalikan kondisi perbankan yang lebih baik perlu adanya penanganan khusus tentang lembaga intermediasi keuangan, maka pemerintah telah mengeluarkan kebijakan yang bersifat nasional yaitu diantaranya: 1) Penerbitan obligasi pemerintah untuk program rekapitulasi; 2) Program Penjaminan dan Bantuan Likuiditas Bank Indonesia (BLBI); dan 3) Program Pemberian Kredit.

Berkaitan dengan hal itu, dalam hal kebijakan tentang penerbitan obligasi, sikap pemerintah hingga saat ini masih konsisten yaitu melanjutkan rencana pengamanan perbankan nasional dan menjaga kepercayaan pasar terhadap pemerintah sebagai penerbit obligasi. Pada sisi lain, kebijakan ini memberikan kebebasan pada para pelaku perbankan untuk melaksanakan usahanya serta perlu dilakukan regulasi dan supervisi yang ketat dalam melindungi bank.

Menurut staf ahli Menteri Negara Pelaksanaan Penyehatan Perbankan, proses pemulihan intermediasi perbankan yang belum berjalan dengan normal ditandai oleh masih rendahnya pertumbuhan kredit. Hal ini disebabkan oleh diantarnya: 1) Terbatasnya debitur potensial sehingga penyaluran kredit 
yang baru hanya diberikan dalam bentuk kredit kecil dan menengah untuk tujuan konsumsi; 2) Perbankan menilai resiko usaha masih tinggi dan komitmen kredit belum disalurkan secara optimal karena belum didukung oleh iklim usaha yang kondusif; 3) Beberapa bank rekapitalisasi yang masih mengalami masalah likuiditas menghadapi kesulitan menjual obligasi rekap, sebab pasar sekunder obligasi pemerintah belum berkembang; dan 4) Beberapa bank masih menghadapi kesulitan untuk memenuhi ketentuan CAR (Capital Adequancy Ratio) dan BMPK ( Batas Maksimum Pemberian Kredit).

Berdasarkan data Bank Indonesia (2008), sepanjang tahun 2004-2008 pertumbuhan asset perbankan terus mengalami peningkatan hampir $10 \mathrm{kali}$ lipat dari 272.3 T menjadi 2310.6 T. Peningkatan ini diikuti dengan pertumbuhan kredit yang juga mengalami perkembangan, tetapi itu belum dapat meningkatkan fungsi intermediasinya, karena tingkat suku bunga SBI yang masih tergolong tinggi. Pada sisi LDR menunjukkan peningkatan yang cukup baik walaupun sedikit yaitu pada tahun 2008 tingkat rasio LDR nya mencapai $77.2 \%$. Disamping rasio yang mulai meningkat dan membaik, pada tingkat NPL presentasenya mengalami penurunan, tetapi penurunan ini justru berdampak baik pada perbankan karena jumlah kredit bermasalah menjadi turun dari $5.8 \%$ menjadi $3.8 \%$. Sementara pada rasio CAR menunjukkan peningkatan pada tahun 2004-2006 sebesar 19.4\% menjadi $20.5 \%$. Pada tahun 2008, rasio CAR mengalami penurunan yang cukup banyak sekitar $4.3 \%$ menjadi $16.2 \%$.

Berdasarkan data Bank Indonesia (2008), tingkat suku bunga SBI mengalami perubahan yang fluktuatif. Perubahan ini dimanfaatkan oleh bank untuk menanamkan dananya pada SBI.
Puncak tingkat suku bunga SBI tertinggi pada tahun 2004-2008 terjadi pada tahun 2005 yaitu sebesar $12.75 \%$, sedangkan tingkat suku bunga SBI terendah terjadi pada tahun 2004 yaitu sebesar $7.43 \%$. Berubah-ubahnya tingkat suku bunga ini sangat dimanfaatkan oleh perbankan.

Berdasarkan uraian diatas maka dalam penelitian ini bertujuan utuk mengetahui apakah CAR, NPL, dan suku bunga SBI berpengaruh terhadap LDR, dan diantara variabel diatas, variabel manakah yang paling berpengaruh terhadap LDR.

\section{TINJAUAN PUSTAKA}

Jika dilihat dari jumlah kecukupan modal dengan jumlah kredit yang disalurkan diduga akan berpengaruh positif. Menurut Siamat (2005): dengan modal bank yang cukup atau banyak sangat penting karena modal bank dimaksudkan untuk memperlancar operasional sebuah bank Jika modal suatu bank meningkat, maka jumlah kredit yang disalurkan juga meningkat dan sebaliknya jika modal bank menurun, maka akan berpengaruh terhadap penurunan jumlah kredit yang disalurkan.

Jika dilihat dari kondisi perekonomian sekarang ini, kredit macet sangat berpengaruh terhadap jumlah kredit yang disalurkan oleh perbankan. Seperti saat ini yang menjadi permasalahan di Indonesia yaitu presentase kredit macet yang tinggi menyebabkan pihak bank enggan menyalurkan kreditnya karena harus membentuk cadangan penghapusan yang besar. Jadi hubungan antara kredit macet dengan jumlah kredit yang disalurkan diduga negatif karena jika presentase kredit macet tinggi maka jumlah kredit yang disalurkan rendah.

SBI merupakan instrumen utang yang diterbitkan oleh pemerintah atau oleh bank sentral atas tunjuk dengan 
jumlah tertentu yang akan dibayarkan kepada pemegang pada tanggal yang telah ditetapkan. Menurut Taswan (2005), SBI adalah surat berharga yang dikeluarkan oleh Bank Indonesia sebagai pengakuan utang jangka pendek dengan sistem diskonto/bunga. Oleh Bank Indonesia, SBI digunakan untuk mengontrol kestabilan nilai Rupiah. Dengan menjual SBI, Bank Indonesia dapat menyerap kelebihan uang primer yang beredar. Tingkat suku bunga yang berlaku pada setiap penjualan SBI ditentukan oleh mekanisme pasar berdasar sistem lelang.

Untuk saat ini SBI menjadi acuan bagi bank karena dinilai lebih menguntungkan. Keuntungan yang didapat jika dari pihak bank selalu menanamkan modalnya ke SBI adalah pihak bank sendiri tidak perlu memutar otak dan menghabiskan energi untuk menyalurkan kredit modal kerja dan investasi yang akan menumbuhkan sektor riil. Bank sendiri merasa sudah cukup mendapatkan pendapatan yang berasal dari return SBI dan juga pendapatan dari jasa-jasa perbankan dan produk-produk yang ada. Dengan pendapatan yang cukup itu menjadikan bank tersebut dikatakan bank yang sehat, padahal tugas utama dari bank yaitu fungsi intermediasinya belum berjalan dengan lancar.

Jika dilihat dari kenyataan yang ada saat ini, bank lebih senang untuk menginvestasikan dana yang telah dihimpunnya dalam bentuk SBI dalam jumlah banyak karena dinilai lebih menguntungkan dan beresiko kecil. Bank sendiri belum berani menyalurkan kredit dalam jumlah yang banyak karena beresiko tinggi seperti kredit macet yang saat ini merupakan masalah perbankan di Indonesia. Jadi hubungan antara SBI dengan LDR diduga mempunyai pengaruh yang negatif karena menyebabkan fungsi intermediasinya tidak berjalan dengan baik.

\section{METODE PENELITIAN}

Jenis penelitian yang dilakukan adalah penelitian deskriptif kuantitatif yaitu penelitian yang dilakukan dalam bentuk data atau angka yang kemudian dianalisa, diklasifikasi dan diinterpretasikan dalam bentuk uraian. Penelitian ini akan menganalisis pengaruh CAR (Capital Adequancy Ratio), NPL (Non-Performing Loan) dan suku bunga SBI terhadap LDR (Loan to Deposit Ratio). Data yang digunakan pada penelitian ini adalah data sekunder time series pada tahun 2004 sampai dengan 2008 yang dipublikasikan oleh Bank Indonesia.

Sampel yang digunakan pada penelitian ini adalah menggunakan purposive sampling yaitu tehnik pengambilan data yang diambil secara acak yaitu bank-bank umum yang go public di BEI. Dari hasil data yang ada, maka sampel data yang digunakan ada 16 bank dari 30 bank go public yang ada di BEI.

Variabel yang digunakan pada penelitian ini meliputi: pada variabel dependen/terikat (Y) adalah Kemempuan intermediasi (LDR) sedangkan pada variabel independent/bebas (X) adalah CAR (Capital Adequancy Ratio) $\left(\mathrm{X}_{1}\right)$, NPL ( Non-Performing Loan) $\left(\mathrm{X}_{2}\right)$ dan suku bunga $\mathrm{SBI}\left(\mathrm{X}_{3}\right)$.

Alat yang digunakan adalah dengan menggunakan analisis regresi berganda, yang merupakan regresi lebih dari dua variable. Untuk mengetahui variable independent (X) terhadap variable dependent (Y), maka digunakan regresi linier berganda dengan rumus: $\mathrm{Y}=\mathrm{a}+\beta_{1} \mathrm{X}_{1}+\beta_{2} \mathrm{X}_{2}+\beta_{3} \mathrm{X}_{3}+\mathrm{e}$

Dimana : $\mathrm{Y}=$ Kemampuan Intermediasi $(\%) ; X_{1}=$ Kecukupan modal $(\%) ; \mathrm{X}_{2}=$ Kendala kredit $(\%) ; \mathrm{X}_{3}$ $=$ Suku bunga SBI (\%); $\alpha=$ 
Konstanta; $\beta_{1} \beta_{2} \beta_{3}=$ Koefisien Regresi; e $=$ Kesalahan Pengganggu.

\section{PEMBAHASAN}

Berdasarkan data yang diperoleh peneliti, maka dapat diketahui perkembangan LDR dari tahun 2004 2008 di masing-masing bank. Hal ini dapat dilihat pada tabel 1 .

Rasio ini biasanya disebut dengan rasio likuiditas yang dapat digunakan untuk mengukur tingkat presentase jumlah penyaluiran kredit perbankan. Suatu bank dapat dikatakan liquid apabila bank yang bersangkutan dapat membayar semua hutang - hutangnya terutama simpanan tabungan, giro, dan deposito pada saat ditagih dan dapat pula memenuhi semua permohonan kredit yang layak dibiayai.
Bank yang memiliki LDR paling tinggi di tahun 2004 adalah PT. Bank Central Asia Tbk sebesar 92.5\%, sedangkan pada tahun 2005 LDR paling tinggi dan paling rendah yaitu PT. Bank Central Asia Tbk sebesar $85.35 \%$ dan Bank Victoria Internasional Tbk sebesar 41.2\%. Pada tahun 2006 tingkat LDR yang paling tinggi adalah Bank Mayapada Tbk sebesar 85.29\%, sedangkan pada tahun 2007 LDR paling tinggi dan paling rendah yaitu Bank Mayapada Tbk sebesar 104\% dan Bank Nusantara Parahyangan Tbk sebesar 49.4\%. Kemudian pada tahun 2008 tingkat LDR paling tinggi adalah Bank Mayapada Tbk dan yang paling rendah yaitu Bank Mega Tbk.

Tabel 1. Perkembangan Loan to Deposit Ratio (\%) Tahun 2004 - 2008

\begin{tabular}{clcccccr}
\hline NO & \multicolumn{1}{c}{ NAMA BANK } & 2004 & 2005 & 2006 & 2007 & 2008 & RERATA \\
\hline 1 & PT BANK CENTRAL ASIA Tbk & 85.37 & 85.35 & 84.78 & 92.5 & 87.93 & 87.192 \\
2 & PT BANK DANAMON Tbk & 77.49 & 80.82 & 75.51 & 88.1 & 86.42 & 81.658 \\
& PT BANK EKSEKUTIF & & & & & & \\
3 & INTERNATIONAL Tbk & 89.98 & 83.6 & 74.8 & 78.1 & 71.04 & 79.496 \\
& PT BANK INTERNASIONAL & 43.62 & 55.3 & 57.22 & 76.2 & 79.45 & 62.352 \\
4 & INDONESIA Tbk & 74.66 & 55.4 & 69.5 & 68.5 & 52.32 & 64.068 \\
5 & PT BANK KESAWAN Tbk & 51.84 & 49.97 & 55.02 & 52 & 56.89 & 53.148 \\
6 & PT BANK MANDIRI Tbk & 73.74 & 82.35 & 85.29 & 104 & 100.2 & 89.096 \\
7 & PT BANK MAYAPADA Tbk & 64.67 & 46.74 & 42.7 & 51.5 & 48.8 & 50.886 \\
8 & PT BANK MEGA Tbk & 55.1 & 54.24 & 48.98 & 60.6 & 68.61 & 57.498 \\
9 & PT BANK NEGARA INDONESIA Tbk & 77.34 & 77.62 & 82.17 & 89.1 & 76.69 & 80.592 \\
10 & PT BANK NISP Tbk & & & & & & \\
& PT BANK NUSANTARA & 52.39 & 57.03 & 54.83 & 49.4 & 66.12 & 55.952 \\
11 & PARAHYANGAN Tbk & 72.93 & 55.17 & 80.47 & 92.4 & 78.93 & 75.972 \\
12 & PT BANK PAN INDONESIA Tbk & 57.2 & 78.5 & 83.1 & 88 & 81.8 & 77.72 \\
13 & PT BANK PERMATA Tbk & 75.69 & 77.83 & 72.53 & 68.8 & 79.93 & 74.956 \\
14 & PT BANK RAKYAT INDONESIA Tbk & 54.11 & 55.39 & 54.89 & 62.2 & 83.11 & 61.932 \\
15 & PT BANK SWADESI Tbk & 54.72 & 41.2 & 51.94 & 55.9 & 53.46 & 51.448 \\
16 & PT VICTORIA INTERNASIONAL Tbk & 66.3 & 64.782 & 67.11 & 73.6 & 73.23 & \\
& Rata - Rata & & 0.23 & -3.46 & -8.15 & 0.5 & \\
\hline Pertumbuhan & & & & & &
\end{tabular}


Tabel 2. Perkembangan Capital Adequancy Ratio (\%) Tahun 2004-2008

\begin{tabular}{clcccccr}
\hline NO NAMA BANK & \multicolumn{1}{c}{ NAM } & 2004 & 2005 & 2006 & 2007 & 2008 & RERATA \\
\hline 1 & PT BANK CENTRAL ASIA Tbk & 23.84 & 22.66 & 22.21 & 18.79 & 15.56 & 20.612 \\
2 & PT BANK DANAMON Tbk & 27 & 23.48 & 22.37 & 20.57 & 13.99 & 21.482 \\
3 & PT BANK EKSEKUTIF INTERNATIONAL Tbk & 14.69 & 11.3 & 9.37 & 11.91 & 9.34 & 11.322 \\
4 & PT BANK INTERNASIONAL INDONESIA Tbk & 20.89 & 22.41 & 24.08 & 21.35 & 19.93 & 21.732 \\
5 & PT BANK KESAWAN Tbk & 12.58 & 14.34 & 9.43 & 10.36 & 10.43 & 11.428 \\
6 & PT BANK MANDIRI Tbk & 25.28 & 23.65 & 25.3 & 21.11 & 15.72 & 22.212 \\
7 & PT BANK MAYAPADA Tbk & 14.43 & 14.24 & 13.82 & 29.95 & 23.69 & 19.226 \\
8 & PT BANK MEGA Tbk & 13.53 & 11.13 & 15.92 & 14.21 & 16.16 & 14.19 \\
9 & PT BANK NEGARA INDONESIA Tbk & 17.13 & 16.67 & 15.95 & 17.65 & 14.38 & 16.356 \\
10 & PT BANK NISP Tbk & 15.11 & 19.95 & 17.3 & 16.48 & 17.27 & 17.222 \\
11 & PT BANK NUSANTARA PARAHYANGAN Tbk & 12.86 & 10.78 & 16.64 & 17.62 & 14.11 & 14.402 \\
12 & PT BANK PAN INDONESIA Tbk & 40.19 & 30.58 & 31.71 & 23.34 & 20.65 & 29.294 \\
13 & PT BANK PERMATA Tbk & 11.4 & 9.9 & 14.4 & 14 & 11.1 & 12.16 \\
14 & PT BANK RAKYAT INDONESIA Tbk & 17.89 & 16.25 & 19.97 & 16.66 & 13.67 & 16.888 \\
15 & PT BANK SWADESI Tbk & 25.95 & 24.06 & 26.55 & 20.66 & 33.27 & 26.098 \\
16 & PT VICTORIA INTERNASIONAL Tbk & 14.92 & 21.92 & 24.02 & 19.58 & 23.22 & 20.732 \\
& Rata-rata & 19.23 & 18.333 & 19.32 & 18.4 & 17.03 & -7.44 \\
& Pertumbuhan & & -4.66 & 5.38 & -4.76 & -7.44 \\
\hline
\end{tabular}

Sumber : Indonesian Capital Market Directory, Pojok BEI (Data Diolah)

Rata-rata LDR pada tahun 2004 sebesar 66.3\%, tahun 2005 sebesar $64.782 \%$, tahun 2006 sebesar $67.11 \%$, tahun 2007 sebesar $73.6 \%$, dan ditahun 2008 sebesar $73.23 \%$.

Berdasarkan data yang diperoleh peneliti, juga diketahui perkembangan CAR dari tahun 2004 - 2008 di masingmasing bank. Hal ini dapat dilihat pada tabel 2.

Rasio ini digunakan untuk mengukur kecukupan modal yang dimiliki bank untuk menunjang aktiva yang menghasilkan resiko, sebagai contoh yaitu kredit. Modal ini tidak mudah untuk diambil oleh pemegang saham.

Pada tabel 2, tingkat presentase CAR yang paling tinggi pada tahun 2004 adalah pada Bank Pan Indonesia Tbk sebesar $40.19 \%$. Sedangkan pada tahun 2005, tingkat presentase CAR yang paling tinggi dan paling rendah yaitu pada Bank permata Tbk sebesar $9.9 \%$ dan Bank Eksekutif Internasional Tbk sebesar 9.37\%. Pada tahun 2006, tingkat presentase CAR yang tertinggi dan terendah yaitu pada Bank Pan Indonesia Tbk sebesar $31.71 \%$. Pada tahun 2007, presentase tingkat CAR tertinggi dan terendah yaitu pada Bank Mayapada Tbk sebesar 29.95\% dan Bank Kesawan Tbk sebesar 10.36\%. Pada tahun 2008, presentase tingkat CAR yang paling tinggi pada Bank Swadesi Tbk sebesar $33.27 \%$ dan yang paling rendah pada Bank Eksekutif Internasional Tbk sebesar 9.34\%.

Presentase tingkat CAR rata - rata pada tahun 2005 ebesar 19.23\%. Pada tahun 2006 rata-rata CAR sebesar 18.333\%. Pada tahun 2007, presentase CAR sebesar $19.32 \%$ dan pada tahun 2008, presentase tingkat CAR sebesar $17.03 \%$

Berdasarkan data yang diperoleh peneliti, juga diketahui perkembangan NPL dari tahun 2004 - 2008 di masingmasing bank. Hal ini dapat dilihat pada tabel 3.

Rasio ini digunakan untuk mengukur presentase kredit macet dengan menggunakan aktiva tetap. Kredit ini merupakan kredit yang 
Tabel 3. Perkembangan Non-Performing Loan (\%) Tahun 2004-2008

\begin{tabular}{clcccccr}
\hline NO NAMA BANK & \multicolumn{1}{c}{2004} & 2005 & 2006 & 2007 & 2008 & RERATA \\
\hline 1 & PT BANK CENTRAL ASIA Tbk & 1.28 & 1.21 & 1.28 & 1.01 & 1.57 & 1.27 \\
2 & PT BANK DANAMON Tbk & 4.02 & 2.58 & 3.31 & 2.27 & 2.43 & 2.922 \\
3 & PT BANK EKSEKUTIF INTERNATIONAL Tbk & 9.67 & 13.53 & 7.89 & 15.17 & 15.49 & 12.35 \\
4 & PT BANK INTERNASIONAL INDONESIA Tbk & 4.01 & 2.88 & 5.34 & 3.12 & 2.66 & 3.602 \\
5 & PT BANK KESAWAN Tbk & 5.79 & 12.76 & 6.2 & 6.81 & 5.79 & 7.47 \\
6 & PT BANK MANDIRI Tbk & 7.43 & 26.66 & 17.08 & 7.33 & 4.69 & 12.638 \\
7 & PT BANK MAYAPADA Tbk & 3.11 & 1.79 & 0.65 & 0.46 & 2.83 & 1.768 \\
8 & PT BANK MEGA Tbk & 1.98 & 1.43 & 1.68 & 1.53 & 1.18 & 1.56 \\
9 & PT BANK NEGARA INDONESIA Tbk & 4.6 & 13.7 & 10.47 & 8.18 & 4.96 & 8.382 \\
10 & PT BANK NISP Tbk & 1.01 & 2.46 & 2.49 & 2.53 & 2.72 & 2.242 \\
11 & PT BANK NUSANTARA PARAHYANGAN Tbk & 0.8 & 0.17 & 3.03 & 1.89 & 1.24 & 1.426 \\
12 & PT BANK PAN INDONESIA Tbk & 7.71 & 9.34 & 7.95 & 3.06 & 4.34 & 6.48 \\
13 & PT BANK PERMATA Tbk & 1.6 & 5.3 & 6.4 & 4.6 & 3.5 & 4.28 \\
14 & PT BANK RAKYAT INDONESIA Tbk & 4.19 & 4.68 & 4.81 & 3.44 & 2.8 & 3.984 \\
15 & PT BANK SWADESI Tbk & 2.66 & 2.63 & 2.55 & 1 & 2.16 & 2.2 \\
16 & PT VICTORIA INTERNASIONAL Tbk & 5.23 & 6.03 & 3.79 & 2.39 & 2.56 & 4 \\
& Rata-rata & 4.068 & 6.6969 & 5.308 & 4.05 & 3.808 & -5.9 \\
& Pertumbuhan & & 64.62 & -20.73 & -29.6 & -5.9 & \\
\hline Sumber : Indonesian Capital Market Directory, Pojok BEI (Data Diolah) & & & & &
\end{tabular}

diberikan kepada pihak ketiga (tidak termasuk kredit kepada bank lain). Rasio ini menunjukkan kemampuan manajemen bank dalam mengelola kredit bermasalah yang diberikan oleh bank.

Pada tabel diatas, tingkat NPL paling tinggi pada tahun 2004 yaitu pada Bank Eksekutif Internasional Tbk sebesar 9.67\% dan yang paling rendah pada Bank NISP Tbk. Pada tahun 2005, tingkat NPL paling tinggi pada Bank Mandiri Tbk sebesar $26.66 \%$ dan yang paling rendah pada Bank Nusantara Parahyangan Tbk sebesar $0.17 \%$. Pada tahun 2006, tingkat NPL paling tinggi dan yang paling rendah adalah pada Bank Mandiri Tbk sebesar $17.08 \%$ dan Bank Mayapada Tbk sebesar $0.65 \%$. Sedanglan pada tahun 2007, tingkat NPL tertinggi dan terendah yaitu pada Bank Eksekutif Internasional Tbk sebesar $15.17 \%$ dan Bank Mayapada Tbk sebesar $0.46 \%$. Pada tahun 2008, tingkat presentase NPL yang tertinggi dan terendah yaitu pada Bank Eksekutif Internasional Tbk sebesar $15.49 \%$ dan Bank Mega Tbk sebesar 1.18\%.
Pertumbuhan presentase NPL pada tahun 2004 sampai dengan tahun 2008 terus mengalami penurunan yang cukup berarti karena jika jumlah kredit bermasalah turun, maka keuangan bank tersebut dapat dikatakan membaik. Tetapi jika kredit bermasalah tersebut terus mengalami peningkatan, maka keuangan bank tersebut dapat dikatakan memburuk.

Adapun suku bunga SBI selama tahun 2004 - 2008 dapat dilihat pada tabel 4.

Tabel 4. Suku Bunga SBI (\%) Tahun 2004-2008

\begin{tabular}{cc}
\hline TAHUN & Suku Bunga \\
\hline 2004 & 7.43 \\
2005 & 12.75 \\
2006 & 9.75 \\
2007 & 8 \\
2008 & 10.83 \\
\hline
\end{tabular}

Suku bunga SBI merupakan salah satu instrument utang yang diterbitkan oleh pemerintah atau bank sentral atas tunjuk dengan jumlah tertentu yang akan dibayarkan kepada pemegang pada 
tanggal yang telah ditetapkan. Pada tabel diatas, puncak tingkat suku bunga SBI tertinggi pada tahun 2004-2008 terjadi pada tahun 2005 yaitu sebesar $12.75 \%$, sedangkan tingkat suku bunga SBI terendah terjadi pada tahun 2004 yaitu sebesar $7.43 \%$. Berubah-ubahnya tingkat suku bunga ini sangat dimanfaatkan oleh perbankan

Sebelum dilakukan pengujian regresi terlebih dahulu dilakukan pengujian asumsi klasik untuk mengetahui apakah data yang digunakan telah memenuhi syarat ketentuan dalam model regresi.

Penelitian ini bertujuan untuk mengetahui nilai-nilai regresi dari masing-masing variabel sehingga dapat diketahui pengaruhnya. Penelitian ini menggunakan data laporan keuangan dari tahun 2004-2008 yang dikumpulkan dalam bentuk tabel-tabel seperti yang terlampir di atas. Data yang diperoleh diolah dengan menggunakan program eviews dengan analisis regresi linear berganda yang selanjutnya data itu akan mengalami proses normalized untuk menentukan koefisien beta/koefisien regresi yang terstandarisasi (standardized regression coeffiency) dari masing-masing variabel.. Dan metode yang dipakai adalah metode kuadrat terkecil biasa (ordinary least square).

Setelah melakukan beberapa kali uji coba, maka didapatkan hasil analisis yang terbaik. Dari hasil analisis itu didapatkan hasil estimasi dari model Tabel 5. Hasil Analisis Regresi regresi yang digunakan pada lampiran dan secara ringkas dapat dilihat pada tabel hasil analisis regresi pada tabel 5 .

Berdasarkan hasil estimasi, dapat ditulis persamaan regresi berganda sebagai berikut:

$\mathrm{Y}=0.886794-0.053241 \mathrm{X} 1-$

$0.139512 \mathrm{X} 2+0.326061 \mathrm{X} 3+\mathrm{e}$

Sebelum dilakukan analisa hasil terhadap hasil estimasi perlu diketahui terlebih dahulu apakah asumsi klasik penggunaan regresi linier berganda sudah dipenuhi atau belum.

Konstanta $\left(\beta_{0}\right)=0.886794 ;$ berarti nilai LDR (Y) pada saat CAR (X1) dan NPL (X2) sama dengan nol atau konstan.

CAR $\left(\beta_{1}\right)=-0.053241$; berarti koefisien regresi variabel CAR (X1) sebesar - 0.053241, berarti ada pengaruh negatif antara CAR terhadap LDR sebesar - 0.053241. Jadi apabila CAR naik $1 \%$, maka LDR akan turun sebesar $5.32 \%$. Sebaliknya, apabila CAR turun sebesar 1\%, maka LDR akan naik sebesar $5.32 \%$ dengan asumsi variabel lainnya tetap.

NPL $\left(\beta_{2}\right)=-0.139512$; berarti koefisien regresi variabel NPL (X2) sebesar - 0.139512 , berarti ada pengaruh negatif antara NPL terhadap LDR sebesar - 0.139512. Jadi apabila NPL naik $1 \%$, maka LDR akan turun sebesar 13.9\%. Sebaliknya, apabila NPL turun sebesar $1 \%$, maka LDR akan naik sebesar $13.9 \%$ dengan asumsi variabel lainnya tetap.

\begin{tabular}{llrrr}
\hline \multicolumn{1}{c}{ Variabel Bebas } & Keterangan & Koef Regresi & \multicolumn{1}{c}{ T-Start } & \multicolumn{1}{c}{ Prob } \\
\hline C & Konstan & 0.886794 & 2.222 .689 & 0.0300 \\
X1 & CAR & -0.053241 & -1.296 .499 & 0.1998 \\
X2 & NPL & -0.139512 & 1.483 .462 & 0.1432 \\
X3 & SBI & 0.326061 & 3.153 .286 & 0.025 \\
\hline
\end{tabular}

$\begin{array}{ll}\text { R-Squared } & =0.206233 \\ \text { Adjusted R-Squared } & =0.166544 \\ \text { F- statistic } & =5.196304 \\ \text { Durbin-Watson stat } & =2.414913\end{array}$


$\operatorname{SBI}(\beta 3)=0.326061 ; \quad$ berarti koefisien regresi variabel $\mathrm{SBI}(\mathrm{X} 3)$ sebesar 0.326061 , berarti ada pengaruh positif antara SBI terhadap LDR sebesar 0.326061 . Jadi apabila SBI naik sebesar $1 \%$, maka LDR akan naik sebesar $32.6 \%$. Sebaliknya, apabila SBI turun sebesar $1 \%$, maka LDR akan turun sebesar $32,6 \%$

Berdasarkan table di atas dapat diketahui bahwa koefisien determinasi (R-Squared) sebesar 0,206233 yang berarti bahwa variabel terikat LDR mampu dijelaskan oleh variabel bebas CAR, NPL dan SBI sebesar 20.62\%\% sedangkan sisanya sebesar $79.38 \%$ dijelaskan oleh variabel lain yang tidak termasuk dalam model. Pertama, variabel CAR $\left(\mathrm{X}_{1}\right)$ tidak ada pengaruh secara nyata terhadap variabel LDR (Y), Kedua, variabel NPL $\left(\mathrm{X}_{2}\right)$ tidak ada pengaruh terhadap LDR $(\mathrm{Y})$. variabel NPL $\left(\mathrm{X}_{3}\right)$ ada pengaruh terhadap LDR (Y).

Dari hasil regresi diatas diperoleh nilai $F_{\text {hitung }}$ sebesar 5,196 dan $F_{\text {tabel }}$ dengan tingkat probabilitas kesalahan 5\% diperoleh nilai $F_{\text {tabel }}$ sebesar 2,72, berarti $F_{\text {hitung }}>F_{\text {tabel }}$ sehingga Ho ditolak dan Ha diterima hal ini berarti variabel CAR, NPL dan SBI ada pengaruh yang signifikan secara simultan antara LDR(Y).

Koefisien determinasi $\left(\mathrm{R}^{2}\right)$ digunakan untuk mengetahui kontribusi variabel bebas terhadap variabel terikat. Nilai $\mathrm{R}^{2}$ besarnya antara $0<\mathrm{R}^{2}<1$, dimana semakin mendekati 1 maka dapat diyatakan model semakin baik.

Dari hasil regresi diperoleh $\mathrm{R} 2=$ 0,206233, berarti kemampuan variabel CAR, NPL dan SBI dalam menjelaskan LDR sebesar 20,62\% sedangkan sisanya sebesar 79,38\% dijelaskan oleh variabelvariabel lain yang tidak dibahas dalam penelitian ini secara implisit tercermin pada variabel pengganggu.
Berdasarkan tujuan penelitian, yaitu untuk mengetahui besarnya pengaruh kecukupan modal, Kendala kredit dan suku bunga SBI terhadap kemampuan intermediasi perbankan dan yang paling mempengaruhi kinerja keuangan. Dapat dilihat dari hasil regresi yaitu model regresi linier berganda bahwa ada hubungan yang searah antara variabel CAR dan NPL terhadap LDR.

Dimana jika kecukupan modal meningkat maka kemampuan intermediasi perbankan mengalami penurunan. Jika NPL mengalami penurunan, maka kemampuan penyaluran kredit akan meningkat. Sedangkan jika SBI meningkat, maka LDR meningkat. Dapat dilihat dari hasil regresi bahwa presentase terbesar diantara ketiga variabel bebas terhadap kinerja diberikan oleh variabel suku bunga SBI, ini terlihat dari nilai koefisien regresi variabel sebesar 0.326061, ini berarti bahwa dengan turunnya kemampuan penyaluran kredit sebesar 1 satuan maka SBI akan naik sebesar 0.,326061 Sedangkan pada variabel CAR dengan koefisien sebesar 0,053241, ini berarti bahwa dengan naiknya CAR sebesar 1 satuan maka kemampuan penyaluran kredit akan turun sebesar $-0,053241$.

Jadi dapat disimpulkan bahwa SBI dominan terbesar bagi kenaikan kinerja keuangan bank yang go public di Indonesia dibanding dengan Kecukupan modal dan NPL. Hal ini disebabkan karena SBI sebagai ancaman terbesar bagi dunia perbankan. SBI merupakan imbas dari krisis perbankan saat ini. Dengan prosentase NPL yang tinggi menyebabkan perbankan lebih senang menempatkan dananya ke dalam SBI.

\section{PENUTUP}

Berdasarkan hasil analisa, besarnya pengaruh kemampuan intermediasi bank sebelumnya, maka 
dapat diambil kesimpulan mengenai fungsi intermediasi perbankan pada 16 bank yang go public selama periode tahun 2004-2008: Pertama, Dari hasil regresi diperoleh hasil bahwa variabel kecukupan modal (CAR) mempunyai pengaruh negatif dan tidak signifikan terhadap kemampuan intermediasi perbankan. Besar $\mathrm{t}$ hitung $<\mathrm{t}$ tabel $(1,296<1,990)$ dengan nilai sinnifikan $(0.1998>0.05)$. hal ini dapat disimpulkan bahwa setiap kenaikan LDR akan diikuti dengan penurunan CAR, dikarenakan setiap bank harus dapat meningkatkan kredit selama peningkatan kredit tersebut tidak mengganggu modal bank itu sendiri sesuai dengan ketentuan Bank Indonesia yaitu sebesar 8\%, untuk memperbaiki infrastruktur bank dan juga jika NPL meningkat, maka CAR menurun karena untuk menutupi NPL yang meningkat tersebut.

Kedua, Dari analisa data yang telah dilakukan secara serentak menunjukkan bahwa variabel NPL memiliki pengaruh negatif dan tidak signifikan terhadap kemampuan intermediasi perbankan(LDR). Hal ini dapat dilihat dari tingkat probability atau signifikansinya, yaitu variabel NPL sebesar $0,1432>0.05$. Selain itu juga dapat dilihat dari uji $F$, yang mana $\mathrm{F}_{\text {hitung }}>\mathrm{F}_{\text {tabel }}$ yaitu sebesar 5,196 $>2,72$, sehingga Ho diterima dan Ha ditolak. Ini dikarenakan dampak dari krisis dunia yang sedang melanda saat ini dan juga dampak dari harga minyak dunia yang meningkat. Meskipun hasilnya signifikan, tetapi bukan berarti NPL diabaikan, namun harus lebih di teliti lagi dalam proses penyaluran kredit dan lebih diselektif lagi dalam pencairan dana kredit.

Ketiga, Pada SBI mempunyai pengaruh yang positif dan signifikan terhadap kemampuan intermediasi perbankan (LDR). Ini dikarenakan dampak dari krisis dunia yang terjadi sehingga menyebabkan hasil NPL tinggi dan bank beralih ke SBI karena dinilai aman tanpa resiko.

Keempat, Dari hasil regresi tersebut juga dapat ditarik kesimpulan bahwa variabel SBI berpengaruh lebih besar secara signifikan terhadap Kemampuan intermediasi perbankan. Hal ini dapat dilihat bahwa nilai koefisiennya sebesar 0.326061 . Sedangkan variabel CAR dan NPL memiliki pengaruh secara signifikan sebesar 0,1998 dan 0,1432. Hal ini menunjukkan bahwa variabel yang memiliki pengaruh lebih besar adalah variabel suku bunga SBI dengan menggunakan alat ukur SBI daripada variabel CAR dan NPL. Karena semakin besar SBI, semakin besar pula gangguan keuangan pada bank tersebut. Jika SBI tinggi, maka tingkat kesehatan bank mengalami penurunan. Karena SBI sebagai acuan bank dalam penyaluran kredit kepada masyarakat atau perusahaan.

Dari hasil studi empiris yang dilakukan mengenai pengaruh CAR, NPL dan SBI terhadap Kemampuan Intermediasi perbankan yang menggunakan alat ukur LDR dapat dibuat saran sebagai berkut: Pertama, Adanya hubungan antara kecukupan modal, kendala kredit, suku bunga SBI dan kemampuan fungsi intermediasi perbankan menunjukkan bahwa variabelvariabel tersebut tidak saling bertentangan dalam mencapai target pertumbuhan ekonomi dalam dunia perbankan. Perlu adanya kebijakan pemerintah untuk terus meningkatkan dan mendorong laju pertumbuhan ekonomi.

Kedua, Penilaian tentang kemampuan fungsi intermediasi perbankan dengan menggunakan analisa kuantitatif tentunya mempunyai keterbatasan, mengingat dengan menggunakan perhitungan rasio LDR 
juga sangat menentukan tehadap kemampuan intermediasi perbankan. Oleh karena itu penelitian selanjutnya hendaknya mamasukkan perhitungan variabel tidak hanya menggunakan alat ukur LDR saja, akan tetapi alat ukur yang lain yang lebih luas sehingga dapat berpengaruh lebih baik terhadap kinerja keuangan bank.

Ketiga, Perlunya peningkatan pengalokasian dana pada CAR dan menurunkan tingkat NPL dan SBI agar bank tersebut dapat menjalankan perusahaannya atau bank kearah yang lebih baik. Karena jika tingkat NPL dan SBI suatu bank tinggi, maka bank tersebut bisa saja mengalami kesulitan keuangan dengan banyaknya kredit macet dan penglihan dana ke SBI yang sekarang ini sering terjadi. Perlu adanya identifikasi lebih lanjut dan perlu adanya seleksi yang sangat ketat dari pihak perbankan itu sendiri Karena kemampuan intermediasi perbankan merupakan salah satu faktor yang penting dalam perbankan. Semakin besar nilai CAR, maka menunjukkan semakin baik keuangan perbankan dan juga semakin kecil nilai NPL dan SBI, maka semakin baik pula keuangan perbankan karena penghasilan dari bunga pinjaman.

\section{DAFTAR PUSTAKA}

Abdullah, Faisal. 2003 . Manajemen Perbankan. Edisi Revisi,UMM PRESS

Arthesa, Ade\& Edia Handyman. 2006. Bank dan Lembaga Keuangan Bukan Bank. Jakarta: PT.INDEKS Kelompok Gramedia.

Fabozzi dkk. 1999. Pasar dan Lembaga Keuangan. Jakarta: Penerbit Salemba Empat.
Kasmir, SE, MM. 2004. Bank dan Lembaga Keuangan Lainnya. Jakarta: Penerbit PT. Raja Grafindo Persada.

Kuncoro, Mudrajad. 2007. Metode Kuantitatif. Yogyakarta: Penerbit Unit Penerbit dan Percetakan (UPP) STIM YKPN

Republik Indonesia, Undang-Undang no.10/1998 tentang Perubahan Undang-Undang no.7/1992 tentang Perbankan. Jakarta.

Siamat, Dahlan. 2001. Manajemen Lembaga Keuangan edisi ketiga. Jakarta: Penerbit Salemba Empat.

Triandaru, Sigit\& Totok Budisantoso. 2006. Bank dan Lembaga Keuangan Lain. Jakarta: Penerbit Salemba Empat.

Taswan. 2005. Akuntansi Perbankan. Edisi Kedua. Jakarta: UPP AMP Y 
